\title{
HYPOCREOPSIS LICHENOIDES P. KARST. (FUNGI, ASCOMYCETES), NEW TO POLAND
}

\author{
MAŁGORZATA STASIŃSKA \\ Departament of Botany, University of Szczecin \\ Felczaka 3a, 71-412 Szczecin, Poland \\ e-mail: stasinsk@univ.szczecin.pl
}

(Received: June 17, 2003. Accepted: August 16, 2003)

\begin{abstract}
Hypocreopsis lichenoides, a fungus found for the first time in Poland, is characterized and illustrated. The paper presents the distribution of the species in Poland and gives its morphological and ecological description.
\end{abstract}

KEY WORDS: Ascomycetes, Hypocreales, peat bog, distribution, Pomerania.

\section{INTRODUCTION}

The genus Hypocreopsis P. Karst. (1873) of the family Hypocreaceae and the order Hypocreales is represented by 5 species, usually growing on decaying wood and often associated with resupinate basidiomycetes. The fungi are widespread, occurring mainly in the Temperate Zone of Europe and North America. Representatives of the genus were also noted in Asia, South America and Africa (Dennis 1978; Niemelä and Nordin 1985; Kirk et al. 2001). Among the species of the genus Hypocreopsis, only one, Hypocreopsis lichenoides (Tode: Fr.) Seaver, was recently found in northern Poland.

Hypocreopsis lichenoides is one of the most easily distinguished fungus of Ascomycetes by size, colour and finger-like forms of stromata. It grows mostly on dead branches of coniferous and deciduous trees, especially species of the genus Salix spp. and Corylus avellana L. This fungus is associated with some species of the Hymenochaetales, mainly Hymenochaete tabacina (Sow.: Fr.) Lév., as a parasite (e.g. Dennis 1978; Niemelä and Nordin 1985; Hansen and Knudsen 2000).

In Central Europe, Hypocreopsis lichenoides seems to be a rare species, known from scattered localities, for example in Germany (Krieglsteiner 1993). This species has not been hitherto noted in Poland. In 2002, during fieldwork in Pomerania, $H$. lichenoides was discovered at several localities in this region. The purpose of this paper is to present the morphology of Polish specimens of the fungus, give the ecological notes and its distribution in Poland.

\section{MATERIAL AND METHODS}

The material was collected from 9 localities in Pomerania (N Poland) in the year 2002. The description of asco- carp morphology and ecological notes are based on original material and supplemented by the literature data. The distribution of Hypocreopsis lichenoides in Poland is presented in a point map. The nomenclature of vascular plants was accepted according to Mirek et al. (1995). Specimens were deposited in the Herbarium of the Department of Botany at the Szczecin University (SZUB), Poland.

\section{RESULTS}

\section{Taxonomy and description}

Hypocreopsis lichenoides (Tode: Fr.) Seaver, Mycologia 2: 82.1910.

Acrospermum lichenoides Tode, Fungi Meckl. 1: 9. 1790; Fries, Syst. Mycol. 2: 246. 1823.

Sphaeria riccioidea Bolton, Fungi Halifax 4: 182. 1791. - Hypocreopsis riccioidea (Bolt.) Karsten, Bidr. Känned. Finlands Nat. Folk. 23: 251. 1873.

For other synonymy see Müller and von Arx (1962) and Strid (1967).

Stromata flat, soft, 1.6-3.6 (-11.0) cm broad and 2-4 (5) $\mathrm{mm}$ thick, divided into radial ridges or separate lobes, with finger-like outgrowths at the margin; pale brown, orangebrown, yellow brown to ochraceous, with lighter margin; smooth when young, then becoming rugose at the center; when mature delicately dotted with ostioles of the immersed round perithecia (Fig. 1). Solitary, rarely gregarious. Asci narrowly cylindrical 8-spored; ascospores uniseriate, elipsoid, broadly fusiform, changing in size and shape, thin-walled, hyaline, almost smooth (ornamented under TEM, according to Candoussau (1990)), 1-septate, (18.0-) 22.0-30.0 × 6.0-9.0 $\mu \mathrm{m}$ (Fig. 2). 


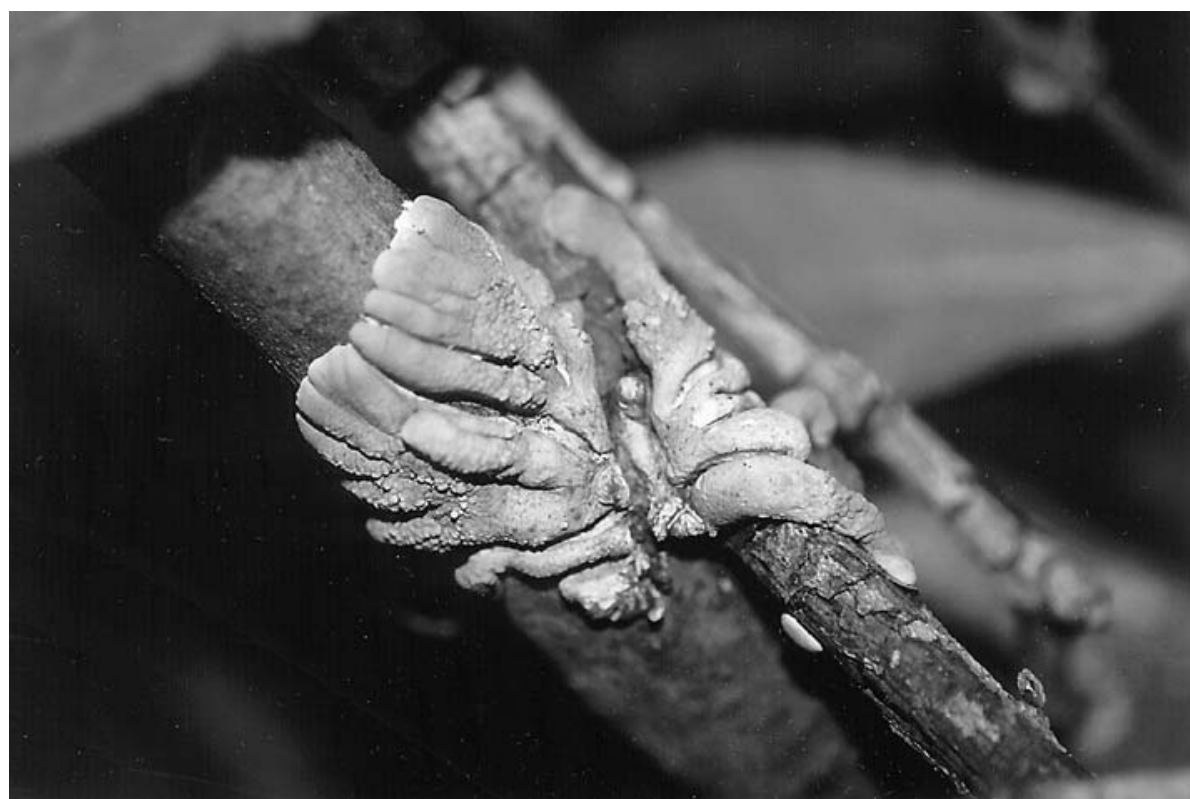

Fig. 1. Ascocarp of Hypocreopsis lichenoides (Tode: Fr.) Seaver.
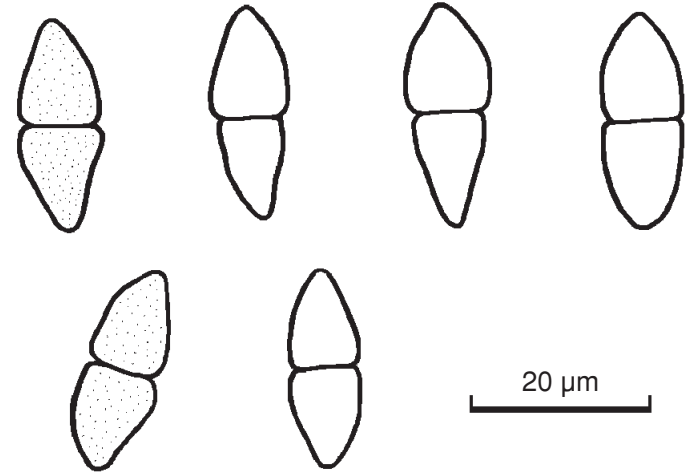

$20 \mu \mathrm{m}$

Fig. 2. Hypocreopsis lichenoides (Tode: Fr.) Seaver: ascospores.

Furthermore, the ascocarps produce abundant globose conidia, which are visible as a brown or reddish-brown mealy powder under the pocket-lens.

\section{Ecological notes}

The specimens of Hypocreopsis lichenoides from Pomerania were found mainly in the marginal part of peat bogs. Individuals of this species were also collected on the lakeside, banks of a water course and a small water reservoir. They grew in shady and moist or temporarily flooded places in willow thickets, classified as Salicetum pentandrocinereae (Almq. 1929) Pass. 1961 (Alnetalia glutinosae R. Tx. 1937 order).

The fruit-bodies were growing on dead, standing or fallen branches and twigs of Salix spp. Some individuals grew on living branches of Salix cinerea L., some on dead twigs near lichens and on two or three dead twigs, touching one another.

These observations correspond with those from Northern Europe. According to Niemelä and Nordin (1985), typical habitats of Hypocreopsis lichenoides are dense, shady grass-herb forests and thickets, rich in dead branches and twigs. In Europe the fungus was recorded particularly on species of the genus Salix (e.g. S. aurita L., S. caprea L. and S. cinerea), Corylus avellana and Padus avium Mill. Furthermore, it was collected e.g. on Frangula alnus Mill., Picea glauca Voss, Populus tremula L., Sambucus racemo- sa L., Symphoricarpos albus (L.) S. F. Blake, Betula sp., Crataegus sp., Pinus sp., Rosa sp. and Rubus sp. (e.g. Dennis 1978; Niemelä and Nordin 1985; Candoussau 1990; Jahn 1990; Hansen and Knudsen 2000).

Hypocreopsis lichenoides was noted on basidiomes of some species of the order Hymenochaetales, especially on Hymenochaete tabacina (e.g. Niemelä and Nordin 1985; Jahn 1990). This relationship has not been observed in Poland. However, individuals of this fungus were often found together with H. tabacina. Jahn (1990) suggested that the species occurred on dead wood previously dacayed by other fungi (e.g. H. tabacina) causing white rot of wood.

\section{Distribution}

Hypocreopsis lichenoides is a widespread species that has a discontinuous Euro-American range in the Northern Hemisphere. In North America it occurs in the United States and Canada (e.g. Cauchon and Ouellette 1964; Strid 1967; Kallio 1980; Niemelä and Nordin 1985). In Europe, the taxon is known mainly in the northern and central parts of the continent, where it is considered as a rare species. On the European continent it was noted in Belgium, Denmark, Finland, France, Germany, Great Britain, Luxemburg, Norway, Spain, Sweden and Russia (e.g. Heim 1952; Nordin 1969; Dennis 1978; Subin and Krutov 1979; Niemelä and Nordin 1985; Candoussau 1990; Krieglsteiner 1993; Hansen and Knudsen 2000).

In Poland, Hypocreopsis lichenoides has been found in nine scattered localities in Pomerania (Fig. 3). For the first time it was noted in the Głębokie Lake Reserve and near Kaliska village, in April 2002. Other localities were discovered mainly in peat bogs in the central and western parts of the region, in the following months of 2002.

In fact, the geographic distribution of Hypocreopsis lichenoides, especially Central Europe, has not yet been delineated. Nordin (1969) and Eckblad (1981) suggested that the distribution of this fungus is expanding in Northern Europe. Niemelä and Nordin (1985) accepted the theory of its expansion. The localities in Poland confirm the expansion of H. lichenoides in Central Europe. 


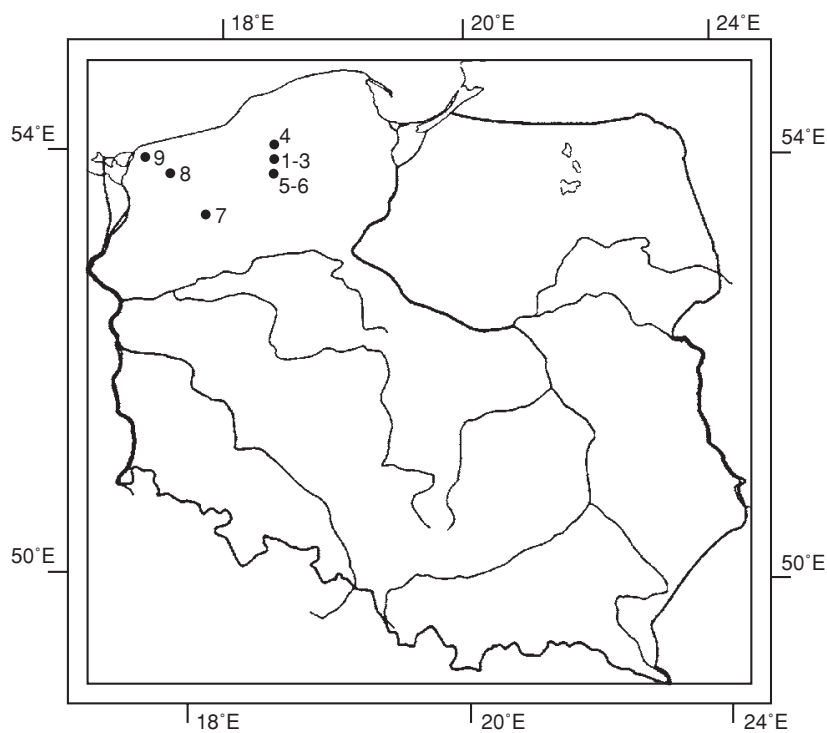

Fig. 3. Distribution of Hypocreopsis lichenoides (Tode: Fr.) Seaver in Poland: 1 - Kaliska, 2 - Głębokie Lake Reserve, 3 - Biały Dwór, 4 - Kołtki, 5 - Kol. Kazimierz, 6 - Kol. Biskupice, 7 - Zarańsko, 8 - Wrzosowisko Sowno Reserve, 9 - Chomino.

\section{Localities in Pomerania ( $N$ Poland):}

1. Small water reservoir near mixed forest, ca $0.5 \mathrm{~km}$ S of Kaliska village; on dead twigs of Salix; 22 April 2002; leg. M. Stasińska.

2. Bank S of Głębokie Lake (reserve); on fallen dead twigs of Salix; 22 April 2002; leg. M. Stasińska.

3. Marginal part of peat bog, ca $0.5 \mathrm{~km} \mathrm{~N}$ of Biały Dwór village; on living branch of Salix cinerea; 16 July 2002; leg. M. Stasińska.

4. Water course, ca $2.5 \mathrm{~km} \mathrm{~N}$ of Kołtki village; on fallen dead twigs of Salix, in Salicetum pentandro-cinereae; 03 May 2002; leg. M. Stasińska.

5. Marginal part of peat bog, ca $0.4 \mathrm{~km} \mathrm{~N}$ of Kol. Kazimierz village; on living branch of Salix cinerea, in Salicetum pentandro-cinereae; 26 June 2002; leg. M. Stasińska.

6. Marginal part of transition bog, S of Kol. Biskupice village; on branch and twig of Salix, in Salicetum pentandro-cinereae; 17 July 2002; leg. M. Stasińska.

7. Marginal part of transition bog, ca $0.2 \mathrm{~km} \mathrm{~S}$ of Zarańsko village; on dead twigs of Salix; 19 October 2002; leg. M. Stasińska.

8. Marginal part of transition bog of the Wrzosowisko Sowno Reserve, ca $1.5 \mathrm{~km}$ NE of Sowno village; on dead twigs of Salix, in Salicetum pentandro-cinereae; 23 October 2002, leg. M. Stasińska.
9. Marginal part of transition bog, ca $2 \mathrm{~km} \mathrm{SW}$ of Chomino village; on dead twig of Salix; 23 October 2002; leg. M. Stasińska.

In Poland, the geographical range of Hypocreopsis lichenoides is still insufficiently known. It seems to be a rare species. Nevertheless, it is expected that further investigations will confirm its occurrence in other parts of Poland.

\section{ACKNOWLEDGMENTS}

This work was financially supported in part by a grant from the State Committee for Scientific Research (KBN) no. 6 PO4C 04519.

\section{LITERATURE CITED}

CANDOUSSAU F. 1990. Hypocreopsis rhododendri in southern France. Mycologist 4 (4): 170-171.

CAUCHON R., OUELLETTE G. 1964. Association of Stromatocrea cerebriforme and Hypocreopsis species with Hymenochaete species. Mycologia 56: 453-455.

DENNIS R.W.G. 1978. British Ascomycetes. J. Cramer, A.R. Gantner Verlag K.G., Vaduz, pp. 585.

ECKBLAD F.-E. 1981. Soppgeografi. Universitetsforlaget, Oslo, pp. 168.

HANSEN L., KNUDSEN H. 2000. Nordic Macromycetes. 1. Ascomycetes. Nordsvamp c/o Botanical Museum, Copenhagen, pp. 309.

HEIM R. 1952. Quelques Ascomycetes remarquables 1. Le genre Hypocreopsis en France. Bull. Soc. Mycol. France 68: 359$-366$.

JAHN H. 1990. Pilze an Bäumen: Saprophyten und Parasiten die an Holz wachsen. Patzer Verlag, Berlin-Hannover, pp. 272.

KALLIO P. 1980. Some observations on the fungi of the central Québec-Labrador penisula. McGill Subarctic Res. Rep. 30: 1-16.

KIRK P.M., CANNON P.F., DAVID J.C., STALPERS J.A. (eds). 2001. Ainsworth and Bisby's Dictionary of the Fungi. 9 ed. CABI Bioscience, Wallingford, pp. 655.

KRIEGLSTEINER G.J. 1993. Verbreitungsatlas der Großpilze Deutschlands (West). 2. Schlauchpilze. E. Ulmer GmbH \& Co., Stuttgart, pp. 596.

MIREK Z., PIĘKOŚ-MIRKOWA H., ZAJAC A., ZAJAC M. 1995. Vascular plants of Poland: a checklist. Polish Bot. Stud. Guideb. Ser. 15: 3-303.

NIEMELÄ T., NORDIN I. 1985. Hypocreopsis lichenoides (Ascomycetes) in North Europe. Karstenia 25: 75-80.

NORDIN I. 1969. Mykologiska notiser. Friesia 9: 79-87.

STRID A.1967. Hypocreopsis lichenoides (Tode ex Fr.) Seaver, a rare ascomycete. Svensk Bot. Tidskr. 61: 79-87.

SUBIN V., KRUTOV V. 1979. Fungi of Karelia and Murmansk region. Nauka, Leningrad, pp. 104. (in Russian) 